\title{
The concept of reference models of automated planning and budgeting systems
}

\section{Emil K. Kamalov}

Postgraduate Student, Department of Business Analytics, Doctoral School of Management

National Research University Higher School of Economics

Address: 20, Myasnitskaya Street, Moscow, 101000, Russian Federation

E-mail:ekkamalov@gmail.com

\begin{abstract}
The article proposes a concept of reference models for automated budgeting systems designed to highlight the cross-subject area between information technologies and budgeting theory. The paper identifies methods of automation of budgeting systems, their reference elements and interaction with the organization budgeting system. In particular, the extension of functionality of spreadsheets, the development of functionality of ERP-systems, customized development of automated budgeting systems, task-oriented budgeting systems and systems available within the "software as a services" (SaaS) model are considered as the main approaches to budgeting automation.

Reference models are taken to mean models of automated budgeting systems which describe the information system configuration for certain sectors or types of production, i.e. a meta description based on which a specific system can be configured and implemented.

For description of a reference model, such documents as a directory of budget items grouped within the analytical dimensions, album of forms (including data entry forms and report forms), as well as passport of algorithms, which describes methods of calculation of budget accounts are proposed to be used. This documentation covers three main areas within which the information systems are designed, namely, design of data objects, design of screen forms and reports, and record of the technology being used.

Reference models of the budgeting systems enable consulting companies to formalize and systematize the project experience to achieve a competitive position through reduction of terms and enhancement of the system integration.
\end{abstract}

Key words: corporate planning, budgeting, automated budgeting system, business performance management, system implementation, reference model, consolidation, analysis, OLAP, industry features.

Citation: Kamalov E.K. (2016) The concept of reference models of automated planning and budgeting systems. Business Informatics, no. 2 (36), pp. 24-31. DOI: 10.17323/1998-0663.2016.2.24.31.

\section{Introduction}

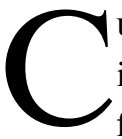
urrently budgeting technology has become an indispensable element of management systems for organizations relating to big business, and it continues to gain popularity among medium-sized companies. As a rule, the area covered by the modern budg- eting system comprises a significant amount of financial, natural and quality metrics and accounts [1]. Therefore, the concept "corporate planning and budgeting" is often used on the same basis as the term "budgeting". The concept of corporate planning and budgeting originated abroad and was borrowed by the domestic budgeting and management accounting practices. 
Planning and budgeting represent a system of more important accounts describing the organizational status at a given time. Moreover, budgeting makes it possible to reflect both the enterprise state in real time (actual), and the target state for a certain time in the future (plan, forecast). Furthermore, budgeting opens up historical data, i.e. actual values of the historic budget accounts.

Budgeting reflects the state of the entire organization that is required for the top management. It also enables us to set benchmarks for mid-level managers. Therefore, the budget items represent aggregative accounts, without inherent itemization at the operational management level, but sufficient to describe all high-priority elements in terms of the management system. However, despite a relatively low level of accounts breakdown, operational budgeting, collection and consolidation of data across the organization (especially in respect to a holding company consisting of multiple, often geographically dispersed organizational units), and especially business analysis turn out to be impossible without automation of the budgeting system $[2,3]$.

\section{Automation specifics of the budgeting system}

Automation of the budgeting system is an important issue, one of the key elements of the information support system (system complex) for corporate and strategic management [4]. It allows us to achieve a synergistic effect of the consolidated information space, all of which greatly enhances business analysis and planning capabilities. This is due to the fact that in the budgeting process of large organizations up to several tens of thousands of budget accounts are used. They are introduced in several versions for different reporting periods (years, quarters, months, etc.), according to different scenarios by a variety of organization units and affiliates. In other words, in the course of the budget process a significant amount of data is generated. It is analyzed and processed by means of classical spreadsheets, and this is extremely nonproductive, as noted in most of the studies on this issue, for example, in papers [2, 5-7]. Analysis of research in the area of approaches to automation of the budgeting systems enables us to identify the following groups of solutions:

automation by extending the functionality of spreadsheets via macros (e.g., table editor MS Excel and VBA); $\checkmark$ extension (improvement) of functionality of ERP systems (e.g., SAP R/3, 1C: Enterprise, MS Dynamics $\mathrm{AX}$, and others);

$\checkmark$ automated budgeting system developed by company IT department or a contractor;

$\checkmark$ customized application issued by the software company (for example, Oracle Hyperion Planning, SAP BPC and others);

$\downarrow$ customized application provided by software companies using the SaaS model (software as a service) (Oracle PBCS, IBM Cognos TM1 on Cloud et al.).

The automated budgeting systems included in each of the above groups have their own advantages and disadvantages. Therefore, the company management making decisions on implementation of one or another option is tasked with searching for an optimum relationship of functionality, reliability, risks, time and cost of the implementation. An extended analysis of this issue is presented, for example, in paper [8]. The following key characteristics of approaches to automation of the budgeting systems can be highlighted:

$\checkmark$ Extension of functionality of the spreadsheets is the lowest cost option per totality of factors, such as user training, license cost, qualification and services cost of IT specialists. However, such solutions have the lowest functionality, performance and reliability. It is worth noting that the maintenance of such a solution is extremely labor-intensive, considering the need to make changes to hundreds of separate documents.

$\diamond$ Improvement of functionality of the ERP system is characterized by an average cost through reduction of expenditures connected with purchasing new licenses and retraining specialists. However, the functionality and performance of this solution are significantly limited, because the systems of this class were originally developed to solve another scope of tasks, namely, operational accounting and management tasks.

The customized automated budgeting system (unique system) is characterized by high cost and labor content (if the system is developed by its own IT department), as well as risks in implementation and maintenance. Theoretically, systems of this kind should cover the company needs in functionality as much as possible, but for that to be so a staff of highly qualified IT specialists and methodologies providing for their development and support has to be maintained. In addition, high time expenditures are required to put such systems into commercial operation in comparison with the purpose-built solutions. In addition, performance comparable to the solutions of software companies can fail. 
Task-oriented systems a priori have broad functionality and high performance, as they were originally designed specifically for budgeting tasks. In addition, software producers from one version to another extend the system capabilities, increase system stability and reliability, drawing on feedback of the system integrators and companies which have implemented and are using this system. Systems of this group generally have a wide range of tools of integration with solutions of other classes: a software company often offers a broad range of its products with seamless interaction. The relatively high cost of implementation of such solutions and the need for user training can be identified as negative factors.

Task-oriented systems using the SaaS model of large software producers tend to have a similar, though slightly lower functionality as compared to classical task-oriented budgeting systems. For smaller software companies, such systems could serve as a main product. The systems of this class are cheaper than the classical purpose-built solutions, due to the fact that the infrastructure and technical support are transferred to the software developer, and the licenses are purchased via a subscription model. This segment is offered primarily to medium-sized business.

From the foregoing, it follows that there is a wide range of methods of budgeting automation and providing solutions. However, from the perspective of technical implementation, task-oriented budgeting systems based on information on-line analytical processing technology (OLAP) [5] are in fact an automation standard for planning and budgeting systems of big business; this term was introduced by B. Codd in 1993 [9]. Thus, according to Gartner research, for a market of corporate performance management (CPM) class systems, which include budgeting systems, such software giants like SAP, Oracle and IBM have become absolute leaders. Their products (both classical applications, and SAS) are based on OLAP technology [10].

The unconditional dominance of OLAP in budgeting automation is explained by the fact that this technology is perfectly suited to collection and consolidation of large volumes of data from various sources, providing an analytical slice with minimal processing time, representing information in a data structure accessible for understanding and analysis by users, and so on [11]. This functionality is present in all major automated budgeting systems.

\section{Reference automated budgeting systems}

The market of automated corporate planning and budgeting systems is mature and highly competitive [10]. At the same time, business competition is observed not only among software companies, but also among consulting companies specializing in implementation of this class of systems. The remarkable thing is that one and the same integrator company can often automate budgeting systems by software products of different vendors.

The following factors may act as a competitive advantage in the system integration market:

- price of implementation of the information system;

- reputation of the integrator company, which can be expressed in a large number of successfully completed projects implementing automated budgeting systems, including in the industry sector relevant to the customer;

- partner status of the software company (usually there are several ratings: platinum partner, gold partner, etc.);

- duration of the life cycle of automated budgeting systems after implementation: if after a few budget cycles the system was taken out of service and was replaced by another solution, this is evidence of negative integration results.

However, the factors listed above for the domestic market are often depreciated due to overrepresentation of the companies involved in this market for a long time. These integrators already have a high partner status of vendors and large project experience. This narrows the range of price changes due to the fact that the major part of the design prime cost is made up of payroll budget of the advice-givers who can move freely among competitive companies, so that a reduction of wages leads to a loss of specialists.

Consequently, competition among integrators goes into the plane of quality and time of implementation. For time- and quality-based competition, many consulting companies offer reference automated budgeting systems - pre-configured versions of the budgeting system, implemented by a product of one vendor and positioned as solutions for a particular industry sector. It is assumed that such an information system meets the basic business needs, so after deployment on servers all that is left to do is to bring it into line with the company's budget model. However, such solutions are most often either very common (only de- 
scribe the framework of master budgets), or based on only one successful project and can be irrelevant to a specific industry as a whole. In addition, in this approach a potential customer is limited by the choice of the software product of one specific vendor. This may motivate cancellation of implementation, especially if the entire information infrastructure of the organization has been built based on solutions of another software company, so that a seamless integration becomes impossible.

\section{Assumptions to formation of the reference model of automated budgeting system}

A significant role in formation of marketing automation standards is played by consulting companies [12, 13], which develop their practice in accordance with the customer's demands. This is embodied both in the form and in the content of the budgeting systems. Most often the budget system itself is subject to changes, and the area of automation is also extended or narrowed down. This leads to the fact that the automation task of the budgeting process is limited to methodology adaptation and its implementation in an information system based on OLAP technology, using a product of one of the software companies. Therefore, in terms of automation, in general, the budgeting system can be represented in the form of one or more data cubes (multi-dimensional representation of budget accounts grouped into analytical dimensions), a set of report forms and calculation algorithms. Based on this abstraction, a concept of reference models of the automated budgeting systems may be proposed. The reference models are taken to mean models of the automated systems, which describe the "information system configuration for certain industries or types of production", i.e., meta description, on which basis configuration and implementation of a particular system can be accomplished [14].

The reference model (meta description) does not have most of the disadvantages specific to the reference solution (specific automated information system), because it is not linked to a particular software product; it is built on the basis of analysis and synthesis of industry specifics drawing on information from various sources (project documentation, industry standards etc.). It is also an intermediate link between the budgeting procedure and the implemented information system. Let us consider the assumptions of forming the concept of the reference model of automated budgeting systems.
It is obvious that a set of budget items grouped within dimensions of data cubes (for example, the dimension of periods may include January, February, March, first quarter, etc., and dimension of scenarios - budget, actual, and forecast) is primary for any automated budgeting system. Definite sets of budget items form "slices" that are presented in the form of input of primary data for users and "mappings" to load data from other systems (e.g., the actual data for the elapsed periods can be loaded from the accounting systems). The input data is processed by certain algorithms and transferred to other analytical slices (groups of budget accounts) which are made available to users in the form of reporting forms. For example, the Profit and Losses (P\&L) budget consolidated per the company corporate divisions may be formed on the basis of budgetary assumptions entered in the input forms by the users.

The system of budget items should describe all important company accounts at a microeconomic level, as well as some macroeconomic measures. These items are directly or indirectly embodied in three consolidated budgets of the company (master budgets): Cash Flow (CF), Profit and Losses (P\&L) and Balance. Master budgets are generated on the basis of more detailed budgets, which can be divided into two groups - operational and financial [15].

In the course of the budget process, any company, irrespective of the industry sector, needs to get three master budgets (in some cases, it may be limited to developing only P\&L or CF). It is obvious that many accounts and dimensions of the budgeting system are universal in some degree. Thus, time periods, budget scenarios, versions, types of data (depending on the source - manual entry, import, calculation etc.), budget items (revenues, expenses, EBITDA and others) organizational structure, internal and external contracting parties, exchange rates can be referred to as universal dimensions. These dimensions are necessary to describe any complicated economic system in competitive market conditions that corresponds to the conceptual budgeting framework. [16] As a natural result, a similar set of dimensions is a mandatory (not variable-based) component of the taskoriented budgeting systems, such as, for example, Oracle Hyperion Planning.

The remarkable thing is that the level of detail and structure of the dimensions noted above are mainly determined by company managerial decision and the budgeting methodology adopted at the company, as well as non-industry specifics. The exception is the dimensions of items and organizational structure. On frequent occasions, it is the industrial sector in which 
the company operates that defines the organizational structure of the grouping of its business units. At the same time, as a general rule the company assets or any other units on which the planning is implemented, can be broken down by types of activity which determine the list of primary budgets and a set of their constituent items. For example, electric power holding companies can include generating and sales assets; oil and gas companies can include upstream, supply and processing; and retail trade can include trade outlets.

The item dimensions for most companies include a hierarchy of accounts conventional for budgeting. For example, the balance sheet incorporates assets, assets incorporate current and non-current assets; noncurrent assets are divided into fixed assets, intangible assets, etc. The industry sector specifics usually show up in the low-level items breakdown. For example, the item "Supplies" in the balance sheet of an electric power holding company will include coal, fuel oil, etc., while the automaker's reserves include finished products and in-progress inventory. The general rule is that this dimension includes groups of items of the inventory balance of resources and engineering-andeconomical performance. These items depend heavily on business specifics, while they owe their existence to industry standards and formats of the state statistical reporting. With regard to the foregoing, the greatest part of measures breaking down the budget items is provided by their removal into separate cube dimensions, which often represent the directions of activities and products. For example, for a car dealer the item "Revenues from sales" can be broken down by type of "Auto sales" activity, and the quality of products can be represented by car and motor trucks, with appropriate model details.

A similar approach is applied to measure business units. As a rule, additional analytic areas (alternative hierarchies) are introduced, thereby allowing us to group the company data in the context of market outlets (for example, "Russia", "neighboring countries", "overseas countries", etc.), types of organizational units (for example, subsidiaries, joint ventures), projects, etc.

It is worth noting the impact of the regulator represented by the state on the models of company automated budgeting systems. A particularly striking example of this impact is taxation: it generates items which are taken into account when calculating the master budget accounts and are used to prepare different variations of budget versions. It can be both items required for any business (VAT, income tax), and specific for cer- tain industry sectors, such as mineral extraction tax (MET) for the mining sector (this item can occupy a significant share of business expenditures). These items are generally calculated (the algorithm is automated). Thus, business can analyze the tax effect on the company in the long term based on the assumptions. This group of measures usually falls within the analytical direction of items or assumptions.

\section{Reference models of automated budgeting systems}

In the foregoing, consideration was given to general assumptions of forming budget items for the reference model of an automated budgeting system. As noted above, the measure sets or groups predetermine the structure of budget forms (budgets). In so doing, rules for item calculations result from their titles, and the algorithms correspond to the financial theory (e.g. EBITDA), or are taken directly from the industry (for example, for the measure "Well water cut, \%" for the oil and gas sector).

Based on the above, let us produce a list of documents corresponding to the concept of a reference model of automated budgeting systems and enabling us to define it. The model can be described by the following documents:

directory of budget items grouped under the analytical measures. The location of the items in the areas (hierarchy relations) and their properties should not be contrary to OLAP principles;

album of forms: the document should present data entry forms and report forms (budgets). The album rows, columns and analytical slice are built based on the item directory;

$\downarrow$ passport of algorithms: the passport describes algorithms for calculating budget accounts (the accounts must also comply with the directory), and it also provides data processing rules.

It is true that the proposed documentation describes data input in the OLAP-cube, as well as data processing and reporting. It covers three main areas in which information systems are designed, i.e. design of data objects, design of screen forms and reports, the account of specific technology [14].

We can thus proceed to the issue of usefulness and approach to the implementation of the solution. Integrator companies can become beneficiaries of the proposed concept application, for which the presence of 
the reference model of the automated system can be used as a competitive position.

Let us consider the process of developing the reference model of the automated budgeting system. No doubt, the development of such a solution calls on the integrator to have highly qualified specialists represented by methodologists having a deep knowledge in the area of budgeting and management accounts, IT specialists (analysts, advice-givers, software researchers), as well as wide project experience in various industries. The remarkable thing is that project experience is represented not only in the form of specialist knowledge, but also in the form of documentation obtained in the course of implementation of the systems in organizations of various industries. As a rule, the integrator company has a large amount of documents, including information applicable to the development of item directories, albums of forms and passports of algorithms. A reference model can be synthesized based on the analysis of this documentation and industrial literature (including scientific literature). Based on expert analysis, specialists need to compare the hierarchical directories and on their basis design new analytical dimensions. In this case the depth of breakdown of certain groups of measures must be determined by a degree of entropy: if a certain group of measures has great variability in different companies, it is recommended to give up a few levels of breakdown, since the presence of items in the model unclear to most customers will not give a positive result.

The model building process cannot be substantially automated, and cannot be implemented by a mathematical tool. This is due to the fact that the titles of budget items in the database of analyzed solutions of different companies can vary widely and be in different languages (especially if a sample for analysis is based on international experience). The level of nesting and descending relations may also differ; in addition, in different projects certain directories can be spread across different analytical areas. As a consequence, the automatic development of calculation rules based on such initial data seems to be even less probable. It follows that the need for semantic analysis and comparison of items distributed in different structures, as well as assessment of their significance makes it impossible to present algorithms for model construction procedures due to the extremely high complexity and uncertainty of the analysis criteria.

\section{Conclusion}

The concept proposed in this paper makes it possible to identify, formalize and systematize the industry sector specifics in the form of a reference model of an automated budgeting system based on project experience and documentation, as well as the industry and general budgeting theory.

The reference model can become a starting point for project work on implementation of the automated budgeting system. Firstly, it allows a potential customer to show the integrator company what exists in budgeting automation in his industry sector. Secondly, based on the model, a system display stand can be developed (the specific software product can vary depending on the buyer requests), which uses the forms and measures familiar to the customer. Thirdly, the presence of a readymade solution can be a starting point for development of a real system that makes it possible to avoid a number of system design errors, reduce the implementation time and increase its quality, all of which fully interest the commercial client and integrator company.

\section{References}

1. Khrutsky V.E., Gamayunov V.V. (2004) Vnutrifirmennoe byudzhetirovanie [Intra-company budgeting]. Moscow: Finance and Statistics (in Russian)

2. Abramova I.V. (2011) Avtomatizatsiya byudzhetirovaniya: chasto zadavaemye voprosy [Automation of budgeting: frequently asked questions]. Management Accounting and Finance, no. 4, pp. 234-240 (in Russian).

3. Makarova V.A. (2011) Organizatsiya finansovogo upravleniya kholdingovykh struktur [Organization of financial management in holding structures]. Saint Petersburg: HSE (in Russian).

4. Isaev D.V. (2011) Primenimost' analiticheskikh informatsionnykh sistem dlya resheniya zadach korporativnogo upravleniya i strategicheskogo menedzhmenta [Applicability of analytical information systems for corporate governance and strategic management purposes]. Audit and Financial Analysis, no. 5, pp. 271-277 (in Russian)

5. Dukhonin E.Yu., Isaev D.V., Mostovoy E.L., et al. (2005) Upravlenie effektivnost'yu biznesa: Kontseptsiya Business Performance Management [Business Performance Management: The conception]. Moscow: Alpina Business Books (in Russian).

6. Zaharov I.V., Formulevich Ya.V. (2008) Avtomatizatsiya protsessa byudzhetirovaniya na predpriyatii [Automation of budgeting process in an enterprise]. ECO. Russian Economic Journal, no. 12, pp. 106-120 (in Russian).

7. Gaponov K.I. (2008) Informatsionnye tekhnologii v upravlencheskom uchete i byudzhetirovanii (avtomatizatsiya upravleniya finansami) [Information technologies in management accounting and budgeting (automation of financial management)]. Management Accounting and Finance, no. 3, pp. 234-242 (in Russian).

8. Kamalov E.K. (2015) Metody avtomatizatsii sistem planirovaniya i byudzhetirovaniya [Methods of automation of planning and budgeting 
systems]. Economics and Management of Control Systems, vol. 3, no. 17, pp. P. 25-33 (in Russian).

9. Codd E.F. Codd S.B., Salley C.T. (1993) Providing OLAP to user-analysts: An IT mandate. Codd \& Associates.

10. Iervolino C., John V.D. (2015) Magic quadrant for Corporate Performance Management suites. Gartner. Available at: https://www.gartner com/doc/reprints?id=1-2D5NXU9\&ct=150407\&st=sb (accessed 04 April 2016).

11. Isaev D.V. (2010) Korporativnoe upravlenie i strategicheskii menedzhment: informatsionnyi aspekt [Corporate governance and strategic management: information aspect]. Moscow: HSE (in Russian).

12. Galliers R.D., Currie W.L. (2011) The Oxford handbook of management information systems: Critical perspectives and new directions. Oxford: Oxford University Press.

13. BPM Standards Group (2005) Business Performance Management industry framework document. Final version 5.0. BPM Standards Group.

14. Grekoul V.I., Denishhenko G.N., Korovkina N.L. (2005) Proektirovanie informatsionnykh sistem [Design of information systems]. Moscow: Intuit (in Russian).

15. Nezamajkin V.L., Yurzianova I.L. (2012) Byudzhetirovanie: metodologiya ili instrument [Budgeting: methodology or a tool]. Finance and Credit, no. 44. pp. 16-21 (in Russian).

16. Shim J.K., Siegel J.G., Shim A.I. (2012) Budgeting basics and beyond. New Jersey: Wiley.

\section{Концепция типовых моделей автоматизированных систем планирования и бюджетирования}

\section{Э.K. Камалов}

аспирант кафедры бизнес-аналитики, аспирантская школа по менеджменту

Национальный исследовательский университет «Высшая школа экономики»

Адрес: 101000, г. Москва, ул. Мясницкая, д. 20

E-mail: ekkamalov@gmail.com

\section{Аннотация}

В статье предложена концепция типовых моделей автоматизированных систем бюджетирования, которая призвана осветить междисциплинарную область между информационными технологиями и теорией бюджетирования. В работе выявлены способы автоматизации систем бюджетирования, их типовые элементы и взаимосвязь с бюджетной системой организации. В частности, в качестве основных подходов к автоматизации бюджетирования рассмотрены расширение функциональности электронных таблиц, развитие функциональности ERP-систем, разработка автоматизированных систем бюджетирования под заказ, специализированные системы бюджетирования и системы, доступные в рамках модели «software as a service» (SaaS).

Под типовыми моделями понимаются модели автоматизированных систем бюджетирования, которые описывают конфигурацию информационной системы для определенных отраслей или типов производства, то есть метаописание, на основе которого может осуществляться конфигурирование и внедрение конкретной системы.

Для описания типовой модели предлагается использовать такие документы, как справочник бюджетных статей, сгруппированных в рамках аналитических измерений, альбом форм (включая формы ввода данных и отчетные формы), а также паспорт алгоритмов, в котором описываются методы расчета бюджетных показателей. Эта документация охватывает три основные области, в рамках которых проектируются информационные системы, - проектирование объектов данных, проектирование экранных форм и отчетов и учет применяемой технологии.

Типовые модели систем бюджетирования позволяют консалтинговым компаниям формализовать и систематизировать проектный опыт для достижения конкурентного преимущества за счет сокращения сроков и повышения качества системной интеграции.

Ключевые слова: корпоративное планирование, бюджетирование, автоматизированная система бюджетирования, управление эффективностью бизнеса, системная интеграция, типовая модель, консолидация, анализ, OLAP, отраслевая специфика. 
Цитирование: Kamalov E.K. The concept of reference models of automated planning and budgeting systems // Business Informatics. 2016. No. 2 (36). P. 24-31. DOI: 10.17323/1998-0663.2016.2.24.31.

\section{Литература}

1. Хруцкий В.Е., Гамаюнов В.В. Внутрифирменное бюджетирование. М.: Финансы и статистика, 2004. 464 с.

2. Абрамова И.В. Автоматизация бюджетирования: часто задаваемые вопросы // Управленческий учет и финансы. 2011. № 4. С. $234-240$.

3. Макарова В.А. Организация финансового управления холдинговых структур. СПб: ВШЭ, 2011. 186 с.

4. Исаев Д.В. Применимость аналитических информационных систем для решения задач корпоративного управления и стратегического менеджмента // Аудит и финансовый анализ. 2011. № 5. С. 271-277.

5. Управление эффективностью бизнеса: Концепция Business Performance Management / Е.Ю. Духонин и [др.]; под ред. Г.В. Генса. М.: Альпина Бизнес Букс, 2005. 269 с.

6. Захаров И.В., Формулевич Я.В. Автоматизация процесса бюджетирования на предприятии // ЭКО. Всероссийский экономический журнал. 2008. № 12. С. 106-120.

7. Гапонов К.И. Информационные технологии в управленческом учете и бюджетировании (автоматизация управления финансами) // Управленческий учет и финансы. 2008. №3. С. 234-242.

8. Камалов Э.К. Методы автоматизации систем планирования и бюджетирования // Экономика и менеджмент систем управления. 2015. T. 3. № 17. C. $25-33$.

9. Codd E.F. Codd S.B., Salley C.T. Providing OLAP to user-analysts: An IT mandate. Codd \& Associates, 1993. 22 p.

10. Iervolino C., John V.D. Magic quadrant for Corporate Performance Management suites. Gartner, 2015. [Электронный pecypc]: https://www. gartner.com/doc/reprints?id=1-2D5NXU9\&ct=150407\&st=sb (дата обращения 04.04.2016).

11. Исаев Д.В. Корпоративное управление и стратегический менеджмент: информационный аспект. М.: ВШЭ, 2010. 215 с.

12. Galliers R.D., Currie W.L. The Oxford handbook of management information systems: Critical perspectives and new directions. Oxford: Oxford University Press, 2011. 725 p.

13. Business Performance Management industry framework document. Final version 5.0. BPM Standards Group, 2005. 27 p.

14. Грекул В.И., Денищенко Г.Н., Коровкина Н.Л. Проектирование информационных систем. М.: Интуит, 2005. 303 с.

15. Незамайкин В.Л., Юрзианова И.Л. Бюджетирование: методология или инструмент // Финансы и кредит. 2012. № 44. С. 16-21.

16. Shim J.K., Siegel J.G., Shim A.I. Budgeting basics and beyond. New Jersey: Wiley, 2012. 544 p. 